http://journal.uhamka.ac.id/index.php/syukur

\title{
PENGARAHAN TENTANG PENTINGNYA PENDIDIKAN USIA DINI DI KAMPUNG BULAK, KECAMATAN PONDOK GEDE, BEKASI
}

\author{
Yadi Nurhayadi dan Agi Aditiya Agasi \\ Universitas Muhammadiyah Prof. DR. HAMKA \\ Email: yadinurhayadi@uhamka.ac.id
}

Diterima: 5 Februari 2018, Direvisi: 13 Februari 2018, Disetujui: 20 Februari 2018

\begin{abstract}
ABSTRAK
Kapabilitas kecerdasan orang dewasa, terkait dengan perkembangan jaringan otak telah mencapai 50 persen ketika ia berumur 4 tahun. Perkembangan pesat jaringan otak terjadi ketika anak berumur 8 tahun dan mencapai puncaknya ketika anak berumur 18 tahun. Setelah itu, walaupun dilakukan perbaikan nutrisi tidak akan berpengaruh terhadap perkembangan kognitif. Periode 4 tahun pertama merupakan periode kritis bagi anak karena sangat berpengaruh terhadap perkembangan periode berikutnya hingga masa dewasa, sementara masa emas ini hanya datang sekali. Optimalisasi pendidikan usia dini, yaitu pendidikan anak di usia 4 tahun pertamanya menjadi sangat penting. Program pengabdian kepada masyarakat ini memberi pengarahan dan pembinaan pentingnya pendidikan usia dini pada masyarakat di wilayah kampung Bulak, Pondok Gede, Bekasi. Kegiatan ini juga dilengkapi dengan aksi filantropi produktif berupa pengadaan sarana perpustakaan bagi anak usia dini.
\end{abstract}

Kata kunci: anak usia dini, jaringan otak, pendidikan

\section{ABSTRACT}

Adult intelligence capabilities, associated with brain tissue development have reached 50 percent when he was 4 years old. The rapid development of brain tissue occurs when the child is 8 years old and reaches its peak when he is 18 years old. After that, although the improvement of nutrition will not affect cognitive development. The first 4year period is a critical period for children because it is very influential on the development of the next period until adulthood, while the golden period only comes once. Optimization of early childhood education, ie education of children at the age of 4 years first becomes very important. This community service program provides direction and guidance on the importance of early childhood education to communities in kampung Bulak, Pondok Gede - Bekasi. This activity is also equipped with productive philanthropy in the form of procurement of library facilities for early childhood.

Keywords: early childhood, brain tissue, education 
Vol. 01, No. 1, pp. 43-52; April 2018

http://journal.uhamka.ac.id/index.php/syukur

\section{PENDAHULUAN}

Daerah Khusus Ibukota Jakarta (DKI Jakarta) adalah ibukota negara dan kota terbesar di Indonesia. Jakarta merupakan satu-satunya kota di Indonesia yang memiliki status setingkat provinsi. Jakarta terletak di pesisir bagian barat laut Pulau Jawa. Dahulu pernah dikenal dengan beberapa nama di antaranya Sunda Kelapa, Jayakarta, dan Batavia. Di dunia internasional, Jakarta juga mempunyai julukan J-Town, atau lebih populer lagi The Big Durian karena dianggap kota yang sebanding New York City (Big Apple) di Indonesia. Sebagai pusat bisnis, politik, dan kebudayaan, Jakarta merupakan tempat berdirinya gedung-gedung menjulang yang menjadi kantor-kantor bagi berbagai lembaga negeri maupun swasta. Gedung-gedung menjulang itu menjadi daya tarik yang menampilkan keindahan ibukota yang menawan bagi banyak masyarakat Indonesia di daerah.

Namun di sisi lain ada pemandangan yang paradoks. Nasib sebagian masyarakat justru sangat mengenaskan. Mereka adalah warga ibukota yang tinggal di daerah pinggiran. Misalnya kehidupan masyarakat di bantaran kali Sunter, Musola AlMuhajirin - Kampung Bulak - Bina Lindung,di wilayah Pondok Gede - Bekasi. Secara umum mereka hidup di bawah garis kemiskinan. Keadaan ini luput dari perhatian banyak orang. Pertumbuhan ekonomi Indonesia tak dirasakan oleh masyarakat yang tinggal di pinggiran kali Sunter ini.

Kini semakin banyak rumah-rumah mewah di sekita wilayah ini. Kehadiran rumah-rumah ini membuat para ibu rumah tangga beralih profesi yang tadinya menjadi pemulung kini menjadi pembantu rumah tangga. Profesi baru ini menimbulkan masalah tersendiri. Kini para ibu rumah tangga menjadi kurang perhatian terhadap anak-anak mereka, terutama yang masih berusia dini. Kesibukan mereka untuk melayani para majikan membuat tak punya banyak waktu untuk memperhatikan buah hati mereka. Padahal pendidikan anak usia dini merupakan hal yang sangat penting dalam rangka pembinaan karakter anak.

Dalam hal ini, Universitas Muhammadiyah Prof Dr. Hamka (UHAMKA) melalui Catur Dharma Perguruan Tingginya turut merasa bertanggung jawab. Melalui dharma ketiga yaitu pengabdian, UHAMKA khususnya Fakultas Ekonomi dan Bisnis Yadi Nurhayadi: Pengarahan tentang Pentingnya Pendidikan Usia Dini 44 di Kampung Bulak, Kecamatan Pondok Gede, Bekasi DOI: $10.22236 /$ syukur_vol1/is1pp43-52 
(FEB), terpanggil untuk memberi pengarahan dan pembinaan pentingnya pendidikan usia dini kepada masyarakat Kampung Bulak. Kegiatan pengabdian kepada masyarakat yang akan diberikan adalah pengarahan dan pembinaan pentingnya pendidikan usia dini. Melalui kegiatan ini diharapkan kesadaran masyarakat akan pentingnya pendidikan anak usia dini meningkat.

\section{MASALAH}

Kementerian Pendidikan dan Kebudayaan Republik Indonesia mewajibkan setiap anak untuk mengikuti pendidikan anak usia dini (PAUD), setidaknya selama setahun, sebelum masuk jenjang sekolah dasar (SD). PAUD dianggap sebagai tahapan penting bagi perkembangan anak. Direktur Jenderal Pendidikan Anak Usia Dini, Nonformal, dan Informal (PAUDNI), Lydia Freyani Hawadi, mengatakan bahwa kegiatan di PAUD dapat memberikan rangsangan atau stimulasi pendidikan yang sesuai dengan tahap tumbuh kembang anak usia pra sekolah. Pendidikan yang diberikan untuk anak usia 3-6 tahun tidak hanya bertujuan mengenalkan anak pada bidang-bidang pelajaran ataupun melatihnya berinteraksi dengan anak sebaya. Lebih jauh dari itu PAUD juga memiliki fungsi utama mengembangkan semua aspek perkembangan anak, meliputi perkembangan kognitif, bahasa, fisik (motorik kasar dan halus), sosial dan emosional.

Namun demikian ternyata tidak semua orang sadar akan hal ini. di Kampung Bulak, Kecamatan Pondok Gede - Bekasi, misalnya, banyak warga masyarakat yang kurang memperhatikan pendidikan anak usia dini. Sebenarnya di daerah ini telah berdiri PAUD dan TK yang diinisiasi oleh organisasi Aisyiyah. Namun kelihatannya animo masyarakat untuk menyekolahkan anaknya masih sangat rendah. Kebanyakan anakanak dibiarkan bermain di bantaran sungai daripada ikut sekolah. 
Vol. 01, No. 1, pp. 43-52; April 2018

http://journal.uhamka.ac.id/index.php/syukur

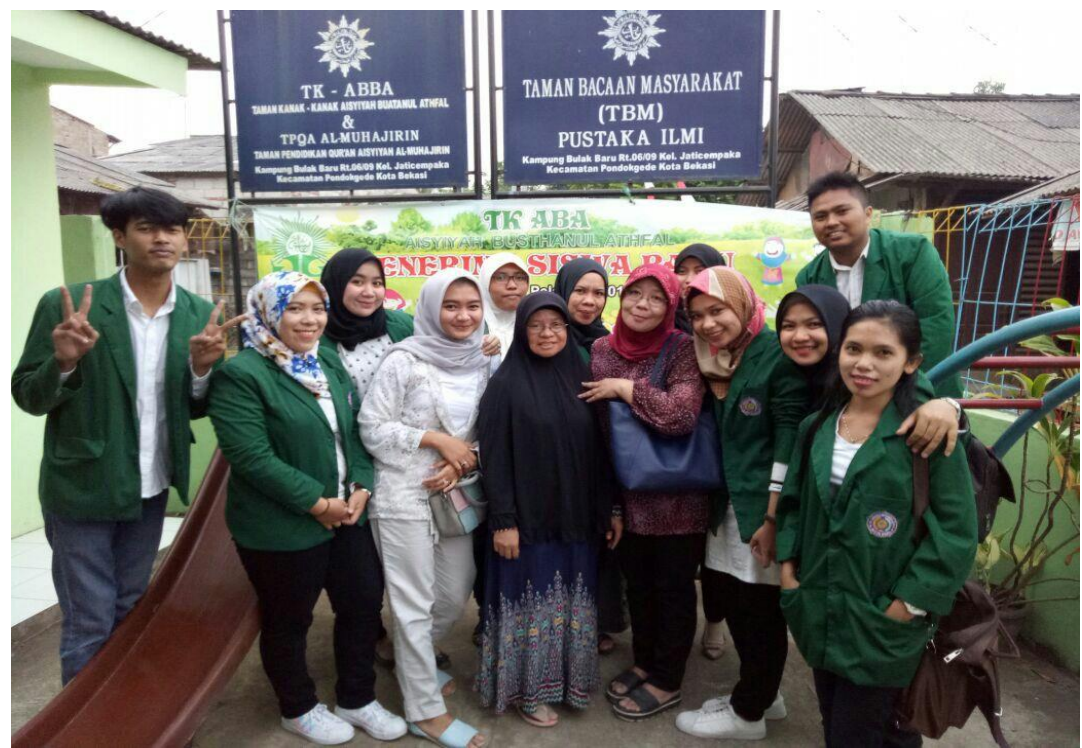

Gambar 3

Taman Kanak-kanak Al-Muhajirin - Kampung Bulak Sumber: Dokumentasi PKM

Berdasarkan identifikasi masalah di atas, maka kegiatan PKM ini aakan diarahkan pada dua sasaran. Perrtama, penyadaran masyarakat akan pentingnya pendidikan anak usia dini. Kedua, membantu mencarikan solusi bagi PAUD yang sudah ada, terutama dalam hal akses pendanaan.

\section{METODE}

Pengabdian kepada masyarakat ini dilaksanakan dengan empat tahap: tahap persiapan, tahap pengalangan dana, tahap pelaksanaan, dab tahap pelaporan. Masingmasing dapat dijelaskan sebagai berikut:

\section{Tahap Persiapan}

Pada tahap ini, tim pengabdian kepada masyarakat melakukan serangakaian persiapan antara lain pembekalan, menjalin komunikasi dengan pihak-pihak, dan melakukan observasi lapangan. Melalui tahap ini tim telah memastikan tempat dilaksanakannya pengabdian kepada masyarakat dan membuat suatu program yang relevan.

Yadi Nurhayadi: Pengarahan tentang Pentingnya Pendidikan Usia Dini 
Vol. 01, No. 1, pp. 43-52; April 2018

http://journal.uhamka.ac.id/index.php/syukur

\section{Tahap Penggalangan Dana}

Pada tahap ini tim melakukan penggalangan dana ke masyarakat. Pada tahap ini tim melakukan sosialisasi program dan mengajak partisipasi masyarakat untuk bersama-sama membantu orang yang membutuhkan.

\section{Tahap Pelaksanaan}

Pada tahap ini seluruh tim turun ke lokasi pengabdian merealiasikan program yang telah dirancang sebelumnya. Tim bekerjasama dengan masyarakat setempat dan pimpinan ranting Muhammadiyah di wilayah tersebut.

\section{HASIL DAN PEMBAHASAN}

Empat tahun pertama perkembangan manusia merupakan masa yang penting. Berdasarkan hasil penelitian, sekitar 50\% kapabilitas kecerdasan manusia telah terjadi ketika ia berumur 4 tahun, lalu $80 \%$ terjadi ketika ia berumur 8 tahun, dan mencapai puncaknya pada umur 18 tahun. Setelah itu, perbaikan nutrisi tidak akan berpengaruh lagi terhadap perkembangan kognitif.

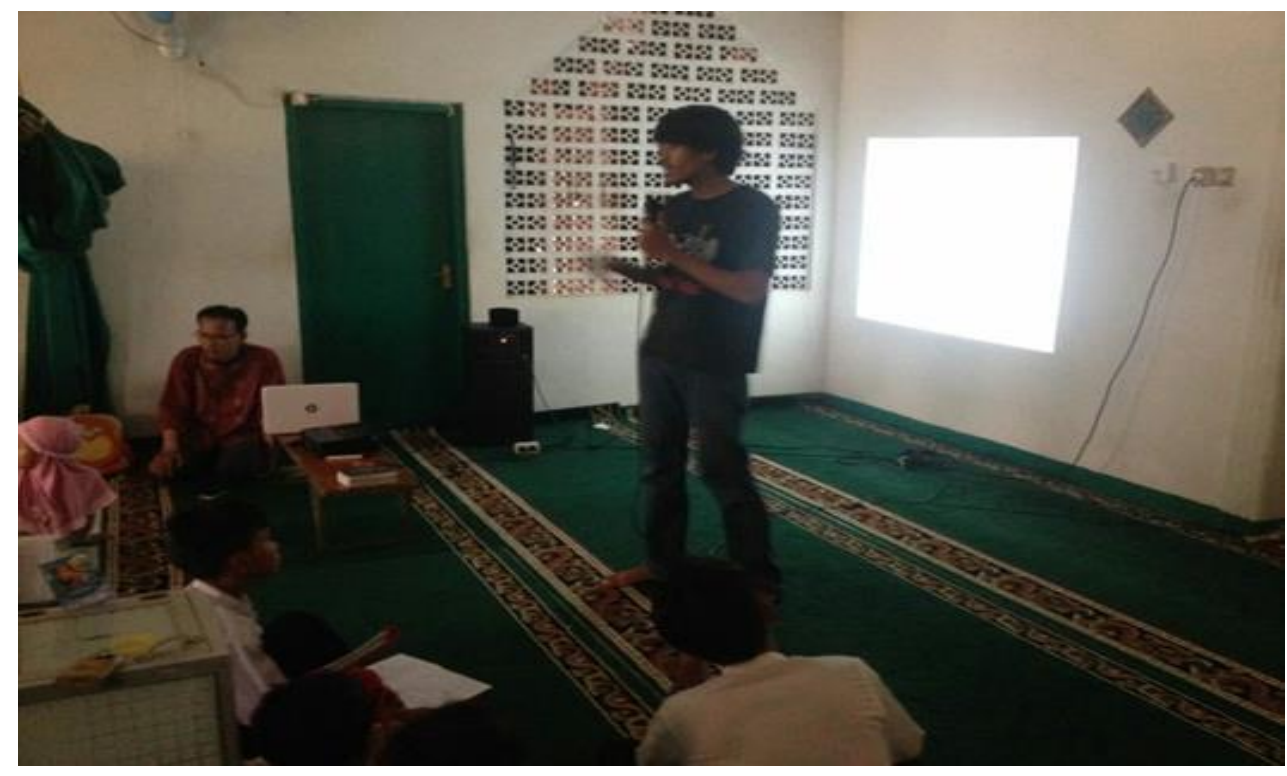

Gambar 4

Pemahaman Pentingnya Pendidikan Usia Dini Sumber: Dokumentasi PKM

Yadi Nurhayadi: Pengarahan tentang Pentingnya Pendidikan Usia Dini di Kampung Bulak, Kecamatan Pondok Gede, Bekasi DOI: $10.22236 /$ syukur_vol1/is1pp43-52 
Perkembangan yang terjadi dalam 4 tahun pertama sama besarnya dengan perkembangan 14 tahun berikutnya. Sehingga 4 tahun pertama usia manusia merupakan periode kritis dimana perkembangan pada periode ini sangat berpengaruh terhadap perkembangan periode berikutnya hingga masa dewasa. Padahal masa emas ini hanya datang sekali. Apabila terlewatkan berarti hilanglah kesempatan memanfaatkannya.

Menurut Byrnes, pendidikan anak usia dini akan memberikan persiapan anak menghadapi masa-masa ke depannya, yang paling dekat adalah menghadapi masa sekolah. Byrnes juga mengatakan bahwa, dewasa ini, beberapa taman kanak-kanak sudah meminta anak murid yang mau mendaftar di sana sudah bisa membaca dan berhitung. Di masa TK ini pula sudah mulai diajarkan kemampuan bersosialisasi dan problem solving. Hal-hal tersebut mungkin terjadi karena kemampuan-kemampuan itu sudah bisa dibentuk sejak usia dini, jelas Byrnes. Maka menurut Byrnes, pendidikan anak usia dini itu penting. Di masa ini harus dibentuk pola pendidikan yang terbaik, yang akan membuat anak siap menghadapi masa sekolah dan masa depannya. Pendidikan usia dini adalah investasi terbaik yang dapat diberikan kepada anak.

Pemahaman pentingnya pendidikan usia dini sesuai konsep di atas telah disampaikan oleh kami, mahasiswa FEB - UHAMKA, sebagai rangkaian kegiatan PKM di Kampung Bulak - Kecamatan Pondok Gede - Bekasi. Para orang tua yang memiliki anak usia dini di Kampung Bulak menjadi memahami pentingnya pendidikan usia dini. Lebih lanjut, penggalangan dana sebagai aksi filantrofi yang diarahkan untuk pengadaan perangkat aktivitas motorik anak usia dini serta pengadaan buku dan raknya telah pula kami laksanakan. Aksi filantrofi yang diarahkan untuk hal produktif ini adalah investasi penting bagi tumbuh kembang anak secara positif.

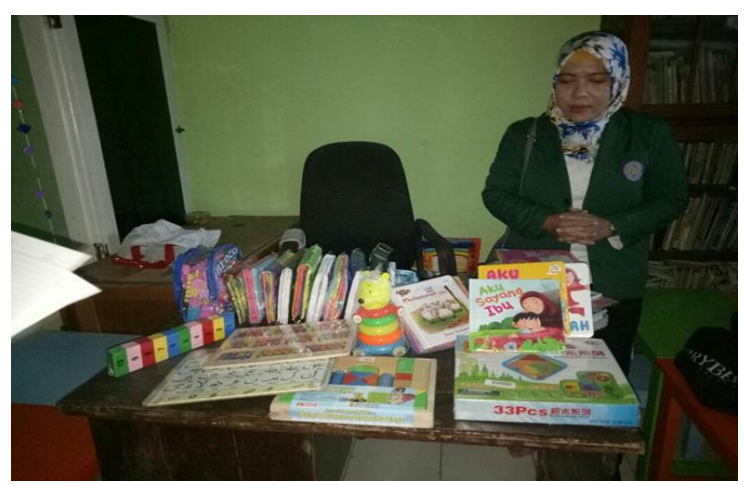

\section{Gambar 5}

Sebagian buku dan perangkat aktivitas motorik untuk anak usia dini.

Sumber: Dokumentasi PKM

Yadi Nurhayadi: Pengarahan tentang Pentingnya Pendidikan Usia Dini di Kampung Bulak, Kecamatan Pondok Gede, Bekasi DOI: 10.22236/syukur_vol1/is1pp43-52 
Vol. 01, No. 1, pp. 43-52; April 2018

http://journal.uhamka.ac.id/index.php/syukur

Sebagai bukti legalitas penggalangan dana yang dilakukan, hasil dari aksi filantrofi ini dilaporkan ke Lembaga Amil Zakat Infak dan Sedekah Muhammadiyah (LAZISMU) - UHAMKA. Atas sepengetahuan Lazismu, dana filantrofi yang terkumpul dibelanjakan untuk membeli buku yang mendidik untuk anak di bawah usia 10 tahun, rak buku, dan perangkat aktivitas motorik. Buku dan raknya akan melengkapi perpustakaan di TK Al-Muhajirin Kampung Bulak.

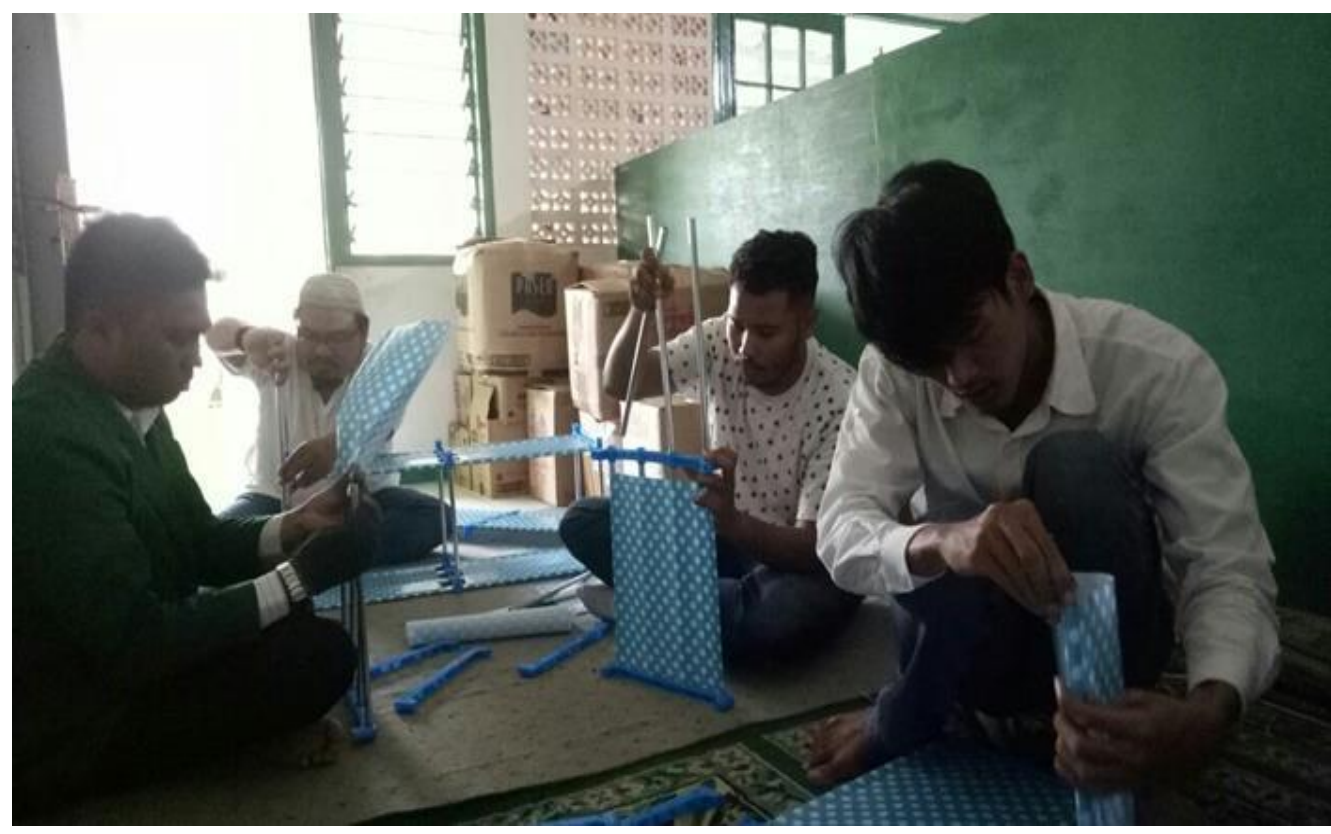

Gambar 6

Perakitan Rak Buku untuk Perpustakaan

Sumber: Dokumentasi PKM

Pengadaan perpustakaan dan perangkat permainan aktivitas motorik anak adalah upaya produktif, yang bermanfaat bagi tumbuh kembang anak usia dini, dibandingkan jika dana yang terkumpul dibelanjakan jamuan makan yang akan sekali habis. Membaca buku yang mendidik dan permainan motorik yang mengasah pemikiran otak akan meninggalkan memori yang positif. Memori positif pada anak akan membuat anak bersikap positif di usia remaja dan dewasanya.

Yadi Nurhayadi: Pengarahan tentang Pentingnya Pendidikan Usia Dini 
Vol. 01, No. 1, pp. 43-52; April 2018

http://journal.uhamka.ac.id/index.php/syukur

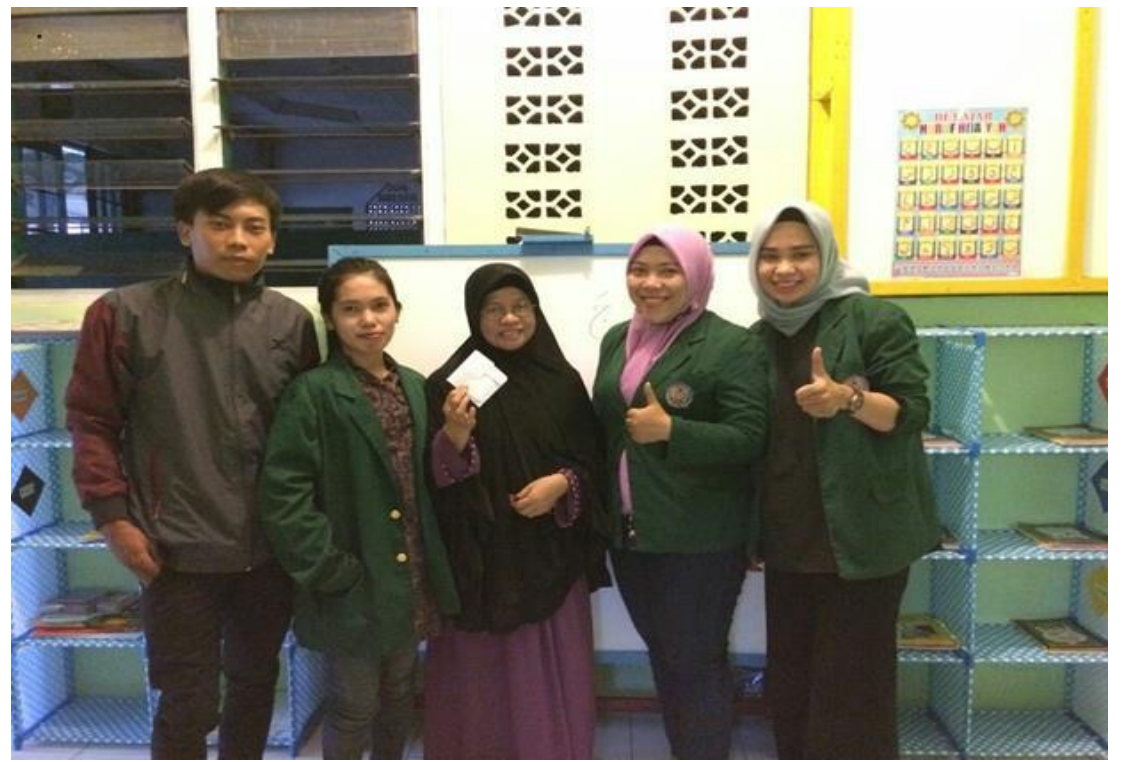

Gambar 7

Tim PKM - FEB UHAMKA diterima dengan baik oleh pendidik PAUD/TK AlMuhajirin, latar belakang adalah rak buku yang telah selesai dirakit Sumber: Dokumentasi PKM

\section{KESIMPULAN}

Berdasarkan hasil kegiatan yang telah dijalankan dapat disimpulkan beberapa hal sebagai berikut.

1. Pendidikan Anak Usia Dini di wilayah-wilayah pinggiran Ibu Kota perlu diperhatikan agar dibina secara sungguh-sungguh. Karena di wilayah ini berkumpul keluarga-keluarga tingkat ekonomi bawah, seperti pemulung, pekerja bangunan, pekerja rumah tangga, dsb. Termasuk di Kampung Bulak, Kecamatan Pondok Gede, Bekasi.

2. Kegiatan Pengabdian Kepada Masyarakat (PKM) yang dilaksanakan oleh Mahasiswa Fakultas Ekonomi dan Bisnis (FEB) - UHAMKA difokuskan pada pemberdayaan Pendidikan Anak Usia Dini atas pertimbangan bahwa ini adalah masalah penting yang harus diselesaikan. Maka dilakukan langkah-langkah dari mulai pemberian pemahaman pentingnya Pendidikan Anak Usia Dini, penggalangan dana melalui aksi filantrofi, pelaporan hasil filantrofi ke LAZISMU, sampai dengan 
Vol. 01, No. 1, pp. 43-52; April 2018

http://journal.uhamka.ac.id/index.php/syukur

eksekusi dana hasil filantrofi untuk pengadaan perpustakaan dan perangkat permainan motorik.

3. Telah terjadi peningkatan kesadaran dan pemahaman pada orang tua di Kampung Bulak, Kecamatan Pondok Gede - Bekasi, akan pentingnya Pendidikan Usia Dini (PAUD). Hal ini ditandai dengan semakin antusiasnya orang tua menitipkan anaknya di PAUD dan TK Al-Muhajirin di Kampung Bulak.

4. Kegiatan PKM yang dilengkapi aksi filantrofi ini telah membangkitkan rasa empati dari warga ibu kota agar memperhatikan masyarakat sekelilingnya yang ada di wilayah pinggiran ibu kota.

5. Telah terjadi peningkatan fasilitas pada yayasan PAUD/TK Al-Muhajirin berupa pelengkapan perpustakaan dan perangkat permainan motorik yang mendidik positif anak-anak usia dini.

\section{DAFTAR PUSTAKA}

Bhawono, Petir lalang. 2012. Metode Pembelajaran Lagu Anak Pada Anak Usia Dini di SPS POS PAUD Sekecamatan Godean. Jogjakarta: Universitas Negeri Jogjakarta.

Byrnes, J. P. 2001. Minds, Brains, and Learning: Understanding the Psychological and Educational Relevance of Neuroscientific Research. New York: Guilford Press.

Diana, Ayu Rohmatin. 2013. Peningkatan Aktivitas dan Hasil Belajar Anak dengan Manfaatkan Media Pembelajaran Berbasis Flash di TK B AL-MADINA SEMARANG. Semarang: Universitas Negeri Semarang.

Sudarmiyanti, Asri. 2014. Pelaksanaan Pembelajaran di Alam PAUD. Bengkulu: Universitas Bengkulu. 